\title{
EVALUATION OF BIOLOGICAL ABSORPTION COEFFICIENT OF TRACE ELEMENTS IN PLANTS FROM THE PITINGA MINE DISTRICT, AMAZONIAN REGION
}

\author{
Maria do Carmo LIMA E CUNHA \\ Lauro Valentim Stoll NARDI \\ Vitor Paulo PEREIRA \\ Artur Cezar BASTOS NETO \\ Luiz Alberto VEDANA
}

\begin{abstract}
Specimens of Ampelozizyphus amazonicus and Adiantum sp., together with adjacent soils, were sampled in the Pitinga Mine District, Amazonian region, in order to investigate the distribution of some trace elements in plants and soils, and their relation to the presence of mineral deposits. The Pitinga Mine contains large deposits of tin, with high concentrations of niobium and zirconium, hosted by the Madeira Granite, which is intrusive into a volcanic sequence named the Iricoumé group, all of them with Paleoproterozoic age. Our results point to the potential use, for both plants, of the Biological Absorption Coefficient (BAC) as an indicator of mineral deposits when the elements involved in this process have moderate to high mobility in the supergene environment. The high BAC for gold indicates that this element can be used as an indicator of gold deposits. The presence of sulfide deposits is indicated by high BAC for $\mathrm{Cu}, \mathrm{Zn}$ and $\mathrm{Pb}$, whereas tin deposits are indicated by increasing BAC for $\mathrm{Y}$ and $\mathrm{Sn}$. This suggests that the BAC of some trace elements in both plants is a good indicator of geochemical enrichment associated with mineral deposits. The importance of biogeochemistry for mineral exploration is confirmed for areas with thick vegetal cover.
\end{abstract}

Keywords: Biologic Absorption Coefficient, biogeochemical prospecting, Pitinga Mine, tin deposits, Amazonian region.

\section{RESUMO}

AVALIAÇÃO DO COEFICIENTE DE ABSORÇÃO BIOLÓGICA DE ELEMENTOSTRAÇO EM PLANTAS DA MINA PITINGA, REGIÃO AMAZÔNICA. Exemplares de Ampelozizyphus amazonicus and Adiantum sp. foram coletados juntamente com amostras de solo na Mina Pitinga, região amazônica, para averiguar a distribuição de alguns elementos-traço nas plantas e no solo e sua relação com a presença da mineralização na área. A Mina Pitinga caracteriza-se por extensos depósitos de estanho, com altas concentrações de nióbio e zircônio no Granito Madeira, que é intrusivo na sequência vulcânica do Grupo Iricoumé, ambas litologias de idade paleoproterozoica. O emprego do Coeficiente de Absorção Biológica (CAB) mostrou-se efetivo em ambas as plantas como indicador de depósitos minerais, quando os elementos envolvidos apresentam moderada a alta mobilidade no ambiente supergênico. Para o ouro o alto valor de CAB ressalta a possibilidade de usar este elemento como indicador de seus depósitos. Depósitos de sulfetos são indicados pelos altos valores de $\mathrm{CAB}$ para $\mathrm{Cu}, \mathrm{Zn}$ e $\mathrm{Pb}$, enquanto os de $\mathrm{Sn}$, pelos significativos valores de CAB do Y e Sn. Sugere-se que o CAB de alguns elementos para ambos os vegetais estudados seja um bom indicador do enriquecimento geoquímico associado a depósitos minerais. Ainda, o emprego da biogeoquímica na exploração mineral é eficaz em áreas de espessa cobertura vegetal.

Palavras-chave: Coeficiente de Absorção Biológica, prospecção biogeoquímica, Mina Pitinga, depósitos de estanho, região amazônica. 


\section{INTRODUCTION}

Some plant species can accumulate metallic elements, which are toxic to plants in general, even in small concentrations. This peculiarity makes certain species useful in mineral exploration programs or in phytoremediation of contaminated soils. Although sometimes these plants do not accumulate significant levels of metallic elements, which is common in geochemically anomalous soils, they are adapted to this environment giving them a character of indicator plants. Additional information on the use of biogeochemistry in mineral exploration in several areas of North America, Australia, South America, Indonesia, Asia, Africa, and Europe was compiled by DUNN (2007).

The humid tropical climate of the Amazonian environment causes weathering of rocks and intense soil leaching with significant loss of most chemical elements. In the supergene environment, precipitation and remobilization of elements in thick sheets of regolith hinder the use of soil geochemistry since they make difficult the identification of the B horizon, which is usually covered by a dense layer of humus and laterite crusts. An additional difficulty lies in sampling along profiles or on regular grids, due to the lack of soil exposures in areas of dense vegetation. In this case, biogeochemistry may be more effective to define geochemical anomalies, since plant roots act as natural samplers, absorbing elements from substrate solutions, and accumulating them in their tissues (BROOKS 1983).

The use of Biogeochemistry as an alternative method of mineral prospecting in the Amazon region should be encouraged. Additionally, further studies on the distribution of trace elements in the Amazonian flora and soil are needed, since these studies will establish a database of the chemical composition of flora, and its relationship with soil and bedrock geochemistry. This research will lay the foundation for future research on plant species tolerance to potentially toxic elements. Moreover, such studies will be useful for the implementation of environmental monitoring programs to prevent pollution from anthropogenic activities, and for the identification of plant species, whose chemical composition will be used in mineral prospecting or as means of remediation of mined-out areas (DUNN \& ANGELICA 2000).

The Pitinga Mine District, located in the Amazonas State, Brazil, contains large tin deposits genetically related to two granite bodies, the Agua
Boa and the Madeira granites, both intruded in a volcanic sequence named Iricoumé Group, which is mainly composed of acid pyroclastic and extrusive rocks (DAOUD 1988, PIEROSAN et al. 2011). This mine, which is one of the world's largest producers of tin, contains important deposits of cryolite and high concentrations of rare metals, such as Zr, Nb, Ta, Y, REE, Li-, Be-, Rb-, and Thenriched minerals, as well as sulfides, which have been reported by several authors (BORGES et al. 2003, HORBE \& PEIXOTO 2006).

The Pitinga Mine is located approximately $300 \mathrm{~km}$ north of the city of Manaus, in an area of rainforest with tropical climate, an annual average temperature of $26^{\circ} \mathrm{C}$, and an annual average precipitation of $2000 \mathrm{~mm}$ (long rainy season between December and May). During intense chemical weathering, the lateritic cover of the Pitinga Mine area formed sandy clay acid soils, which are poor in nutrients (COSTA 1991).

Many petrological (DAOUD 1988, LENHARO 1998, COSTI 2000, PIEROSAN et al. 2011), mineralogical (BASTOS NETO et al. 2005, 2010; PIRES et al. 2006; MINUZZI et al. 2008; NARDI et al. 2012) and, geochemical studies (HORBE et al. 1991, FERRON et al. 2010) have already investigated the granite bodies and associated volcanic rocks of the Pitinga Mine region. However, studies on supergene geochemistry are still scarce (HORBE \& COSTA 1999; HORBE \& PEIXOTO 2006; LIMA E CUNHA et al. 2008, 2012), particularly with regard to the behavior of minor and trace elements.

This study aims to characterize the biogeochemical signature of some trace elements (Ni, Cu, Zn, Ga, As, Se, Rb, Sr, Y, Zr, Nb, Ta, $\mathrm{Mo}, \mathrm{Sn}, \mathrm{Sb}, \mathrm{Cs}, \mathrm{Ba}, \mathrm{W}, \mathrm{Au}, \mathrm{Pb}, \mathrm{Bi}, \mathrm{U}$ and Th Appendix 1), which can be used as indicative of geochemical patterns related to mineralization in the area of the Pitinga Mine. For this purpose, the Biological Absorption Coefficient (BAC), which is the ratio of an element concentration in plants to its concentration in soil, was used. Previous studies (KOVALEVSKY 1979, BROOKS 1983, BAKER 1981, ALLOWAY et al. 1988) have discussed this parameter and indicated it can be used in mineral exploration. According to EBONG et al. (2007), this ratio is a convenient and reliable way to quantify the relative differences in bioavailability of metals to plants. As pointed out by MIAO et al. (2011), the index of biological absorption coefficient can be used to predict the availability of each element in the soil-plant system. 


\section{MATERIALS AND METHODS}

Eighteen pairs of plant and soil samples were collected on the alteration zone of the Biotite Granite (BG) and Albite Granite (ABG), which are both facies of the Madeira Granite, and in the areas of effusive volcanic rocks, pyroclastic and hypabyssal bodies, which make up the Iricoumé Group (Figure 1). Plant species of the family Rhamnaceae Ampelozizyphus amazonicus (local name: saracura-mirá) and Pteridophytes of the genus Adiantum sp. (maidenhair fern) were selected due to their wide distribution and easy identification in the area of the Pitinga Mine.

It was necessary to choose two different types of plants because the biogeochemical signature is a selective mixture of chemical components of the soil/water/rock system. Moreover, each soil horizon contains different concentrations of elements, and each plant species shows different abilities to absorb trace elements from the soil. In this study, leaves were chosen as samples because they are easy to collect; in perennial plants, analytical results are more uniform (less erratic regarding levels of branches). Roots were not sampled due to the difficulty in collecting and the easy contamination with soil elements.

Plant samples (approximately $200 \mathrm{~g}$ of leaves) were first dried at $80^{\circ} \mathrm{C}$ and then, calcined at temperatures of $450-500{ }^{\circ} \mathrm{C}$ for 6 to 8 hours. The resulting ash $(0.25 \mathrm{~g})$ was digested with $\mathrm{HClO}_{4}-\mathrm{HNO}_{3}-\mathrm{HCl}-\mathrm{HF}$ and analyzed by ICP-MS at the ActLabs Laboratory (Canada). The results are expressed in weight of ashes. Soil samples, weighing about $50 \mathrm{~g}$ each, were collected with a manual auger at a depth of approximately $20 \mathrm{~cm}$ at the same sampling location where plants were collected. They were dried at $80^{\circ} \mathrm{C}$, disaggregated in a porcelain grail, and the fraction of $<150$ mesh was used for chemical analysis by ICP-MS after fusion with a flux composed of lithium borate at a temperature of $1000^{\circ} \mathrm{C}$ at the Acme Labs (Canada). The fusion product was digested in a weak nitric acid solution and then aspirated into the ICP-MS to determine the elemental concentrations.

\section{RESULTS AND DISCUSSION}

The composition of plant tissues reflects the composition of the soil in which the plant grows. Concentrations of trace elements in plants depends on several factors, such as abundance in the soil, bioavailability, plant age, speciation of elements, depth of root system and others. Therefore, the variability is generally high. The Biological Absorption Coefficient (BAC) was used to determine the relationship between the concentration of chemical elements in the soil and in the plants. Depending on the magnitude of the coefficient, the elements were classified into five groups: BAC $>10$ - very strongly accumulated; from 1 to 10 - strongly accumulated; from 0.1 to 1.0 - moderate absorption; from 0.01 to 0.1 - weak absorption, and from 0.001 to 0.01 - very weak
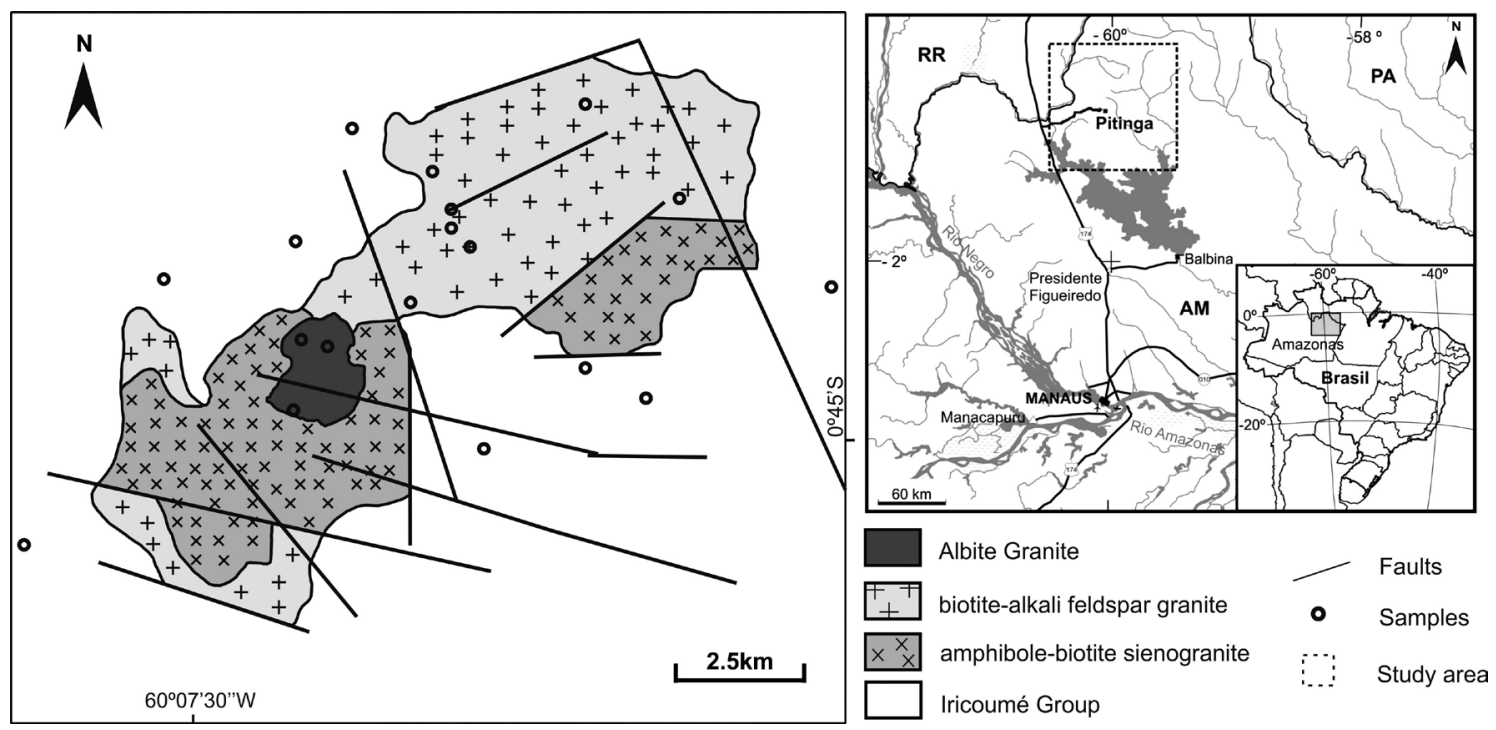

FIGURE 1 - Geologic map of the Pitinga Mine area, showing the localization of sampling sites (modified from LENHARO et al. 2000). 
absorption (KABATA-PENDIAS \& PENDIAS 1984). The increase in BAC in mineralized areas occurs when the elements are present in the form of soluble compounds or as fine-grained disseminations, which results in increasing their availability to plants (KOVALEVSKY 1979).

The evaluation of BAC in pairs of samples of soil and plants collected in the areas of the albite granite and biotite granite facies of the Madeira Granite and in the adjacent volcanic sequence of the Iricoumé Group showed significant BAC values for various elements, as shown in table 1. Two groups of elements stand out, the first consisting of those strongly concentrated in the studied plants (BAC > 10): Ni, Cu, Zn, Se, Rb, Sr and Au. In the second group, elements have lower concentrations in the plant than in the correspondent soil (BAC < 1): Ga, As, Zr, Nb, Ta, Mo, W, Bi, Th and U. A third group with variable behavior was defined, which includes $\mathrm{Y}, \mathrm{Sb}, \mathrm{Cs}, \mathrm{Ba}$ and $\mathrm{Pb}$.

TABLE 1 - Average values of Biological Absorption Coefficient (BAC) in the Pitinga Mine area. Ptdf. $\mathrm{Abg}=$ maidenhair fern in the albite granite facies; Ptdf. $\mathrm{Bg}=$ maidenhair fern in the biotite granite; $\mathrm{Src} \mathrm{Bg}=$ saracura-mirá in the biotite granite; Ptdf. V $=$ maidenhair fern in the volcanic sequence; $\mathrm{Src} \mathrm{V}=$ saracura-mirá in the volcanic sequence.

\begin{tabular}{cccccc}
\hline BAC & Ptdf._Abg & Ptdf._Bg & Src_Bg & Ptdf._V & Src_V \\
\hline $\mathrm{Ni}$ & 24.86 & 0.38 & 10 & 127.3 & 12.1 \\
$\mathrm{Cu}$ & 7.5 & 82.5 & 168 & 138.2 & 157.41 \\
$\mathrm{Zn}$ & 55.95 & 28.6 & 55.65 & 35.18 & 35.65 \\
$\mathrm{Ga}$ & 0.39 & 0.13 & 0.07 & 0.65 & 0.34 \\
$\mathrm{As}$ & 0.48 & 0.24 & 0.23 & 0.62 & 0.39 \\
$\mathrm{Se}$ & 56.47 & 128 & 20 & 40 & 23.68 \\
$\mathrm{Rb}$ & 39.93 & 789 & 365.96 & 20.3 & 111.01 \\
$\mathrm{Sr}$ & 33.9 & 15.83 & 15.85 & 15.3 & 22.13 \\
$\mathrm{Y}$ & 13.62 & 0.53 & 0.02 & 3 & 3.81 \\
$\mathrm{Zr}$ & 0.003 & 0.001 & 0.0004 & 0.001 & 0.001 \\
$\mathrm{Nb}$ & 0.004 & 0.005 & 0.02 & 0.01 & 0.02 \\
$\mathrm{Ta}$ & 0.01 & 0.003 & 0.17 & 0.02 & 0.1 \\
$\mathrm{Mo}$ & 0.04 & 0.015 & 1.73 & 0.07 & 0.35 \\
$\mathrm{Sn}$ & 23.57 & 0.05 & 0.0009 & 2.4 & 3.72 \\
$\mathrm{Sb}$ & 0.12 & 29.5 & 97.4 & 0.66 & 0.41 \\
$\mathrm{Cs}$ & 4.15 & 3.65 & 100.14 & 0.12 & 0.3 \\
$\mathrm{Ba}$ & 0.49 & 2.09 & 0.0013 & 97.9 & 26.87 \\
$\mathrm{~W}$ & 0.047 & 0.01 & 0.02 & 0.07 & 0.08 \\
$\mathrm{Au}$ & 32 & 8.25 & 15.47 & 37.5 & 27.05 \\
$\mathrm{~Pb}$ & 11.06 & 3.98 & 1.3 & 4.3 & 7.45 \\
$\mathrm{Bi}$ & 0.17 & 0.24 & 0.16 & 1.25 & 0.25 \\
$\mathrm{Th}$ & 0.076 & 0.05 & 0.046 & 0.36 & 0.5 \\
$\mathrm{U}$ & 0.047 & 0.038 & 0.042 & 0.15 & 0.08 \\
\hline & & & & &
\end{tabular}

The high BAC for $\mathrm{Cu}, \mathrm{Zn}$, and $\mathrm{Ni}$ obtained in samples collected from the granite and volcanic soils suggests the presence of sulfide mineralization, even though these elements are micronutrients and therefore, actively absorbed by plants. HORBE \& PEIXOTO (2006) reported the enrichment in $\mathrm{Cu}, \mathrm{Pb}$ and $\mathrm{Zn}$ in soils from volcanic rocks in the Pitinga Mine area. BAC for $\mathrm{Se}$ and $\mathrm{Pb}$ is also high, but they are not micronutrients absorbed by most plants and can be toxic to many of them, which also points to the presence of sulfide mineralization, commonly enriched in these chalcophile elements. High concentrations of $\mathrm{Se}$ in plants are a good indication of the presence of sulfide mineralization, as discussed by DUNN (2007). The high BAC for $\mathrm{Au}$, particularly in the fern samples collected in the albite granite and volcanic areas, is probably related to mineralization of this element associated with sulfides. According to DUNN (1995) Au plays no role in plant nutrition, and in areas with mineralization, Au can be accumulated in plants in amounts significantly greater than background levels $(\leq 0.5 \mathrm{ppb})$. Biogeochemical studies on ultramafic soils in southern Brazil reported high concentrations of $\mathrm{Au}(50 \mathrm{ppb})$ associated with $\mathrm{Pd}, \mathrm{Pt}$, and $\mathrm{Ag}$ in fern species (Adiantopsis cf. chlorophylla); additionally, precipitated metallic gold have been identified in plant tissues by scanning electron microscopy (LIMA E CUNHA et al. 2004). High values of $\mathrm{BAC}$ were also observed for $\mathrm{Sb}$ in the $\mathrm{BG}$ area, and this rare element is usually associated with sulfides (BABULA et al. 2008). Although easily absorbed by plants when in a soluble form, $\mathrm{Sb}$ is not an essential element and occurs at very low concentrations. However, in areas with mineralization of $\mathrm{Au}-\mathrm{Sb}-\mathrm{As}$, plants are generally enriched in Sb (DUNN 2007).

The BAC of elements such as $\mathrm{Rb}$ and $\mathrm{Cs}$ in the BG area reaches very high values $(>100)$, although concentrations in the soil are relatively low (c.a. 1-20 ppm). The strong ability of plants of accumulating $\mathrm{Rb}$ and $\mathrm{Cs}$ in impoverished soils is due to the high geochemical mobility of these elements. In areas of volcanic rocks, where the concentrations of $\mathrm{Cs}$ in the soil are far higher than the background of this element (25 ppm according to WHITE \& BROADLEY 2000), the BAC is very low $(<0.4)$. This can be caused by the toxicity of this element triggering the activation of exclusion mechanisms of the plant when its concentration in the soil is too high. Additionally, the adsorption of Cs by clay minerals can reduce its availability to plants in enriched soils (KABATA-PENDIAS \& PENDIAS 1984). 
In the volcanic and granite areas, BAC is relatively high for $\mathrm{Sr}$ in both plants. In addition to its geochemical similarity to $\mathrm{Rb}, \mathrm{Sr}$ is considered an essential element for some plant species, with biochemical functions similar to those of $\mathrm{Ca}$ (KABATA-PENDIAS \& PENDIAS 1984). Sn has low mobility in the supergene environment, and therefore low bioavailability, because it can be strongly absorbed by clay minerals or because it occurs as cassiterite, a detrital phase with low solubility. According to GREGER (2004), Sn has low mobility in soil, but it can be easily absorbed from the solubilized fraction in enriched soil. The high BAC for Sn (>23) observed in plants collected in the albite granite facies, which contains high amounts of disseminated cassiterite, confirms that the increase in the BAC for Sn may be indicative of the presence of mineralization, as proposed by KOVALEVSKY (1979). The BAC for Y (c.a. 13) shows behavior similar to that of Sn. Moreover, $\mathrm{Y}$ concentration is very high in samples of soils and plants from the albite granite facies, which is consistent with the strong enrichment in $\mathrm{Y}$ in the Madeira granite mineralization, as reported by BASTOS NETO et al. (2012). According to WELCH (1984), the BAC for Y in terrestrial plants is 0.003 .

BAC for two characteristic elements of the Pitinga Mine mineralization, $\mathrm{Nb}$ and $\mathrm{Ta}$, is low in the granitic facies and in areas of volcanic rocks, although the soils may show high concentrations of these elements. The low values of BAC are due to the low geochemical mobility of both elements, since they are bound to minerals with low solubility, such as cassiterite, in soils, ores and host rocks, and consequently have low availability to plants. $\mathrm{Nb}$ has low mobility in natural environments (DUNN 2007), since most of the $\mathrm{Nb}$ compounds are slightly soluble in both acid and alkaline media. Weathering fluids have low dissolved $\mathrm{Nb}$ since it remains fixed within resistant minerals and therefore unavailable to plants (KABATA-PENDIAS \& PENDIAS 1984). The low mobility of $\mathrm{Nb}$ in soils is supported by studies by SCHEIB et al. (2012), which estimate that $95 \%$ of niobium in Europe's soils is not available to plants. In this case, as for other trace elements with low mobility, the BAC is not indicative of mineralization.

In the volcanic rocks, for both species, Y, $\mathrm{Sn}$, and $\mathrm{Pb}$ were strongly accumulated (BAC > 1), whereas $\mathrm{Ni}, \mathrm{Cu}, \mathrm{Zn}, \mathrm{Se}, \mathrm{Rb}, \mathrm{Sr}, \mathrm{Ba}$ and $\mathrm{Au}$ were very strongly accumulated, $(\mathrm{BAC}>10)$, as illustrated in figure 2. In the granite areas (Figure $3)$, the saracura-mirá shows BAC greater than 10 for $\mathrm{Ni}, \mathrm{Cu}, \mathrm{Zn}, \mathrm{Se}, \mathrm{Rb}, \mathrm{Sr}, \mathrm{Sb}, \mathrm{Cs}$ and $\mathrm{Au}$. For the ferns, the BAC is greater than 10 for $\mathrm{Zn}, \mathrm{Se}, \mathrm{Rb}, \mathrm{Sb}$ and $\mathrm{Cu}$, and greater than 1 for $\mathrm{Cs}, \mathrm{Ba}, \mathrm{Au}$ and $\mathrm{Pb}$. Ferns collected in the albite granite facies show BAC greater than 1 for $\mathrm{Co}$, $\mathrm{Cu}, \mathrm{Cs}$, and greater than 10 for $\mathrm{Ni}, \mathrm{Zn}, \mathrm{Se}, \mathrm{Rb}$, $\mathrm{Sr}, \mathrm{Y}, \mathrm{Sn}, \mathrm{Au}$ and $\mathrm{Pb}$ (Figure 4). The elements with BAC exceeding 10 in areas covered by the three lithotypes are: Ni, Zn, Se, Rb, Sr and Au. The $\mathrm{BAC}$ for $\mathrm{Sn}, \mathrm{Y}$, and $\mathrm{Pb}$ is greater than 10 in the albite granite facies area; in the biotite granite area, the $\mathrm{BAC}$ for $\mathrm{Cu}, \mathrm{Cs}$, and $\mathrm{Sb}$ is greater than 10 , and in the volcanic terrains, BAC for $\mathrm{Cu}$ and $\mathrm{Ba}$ is greater than 10 .

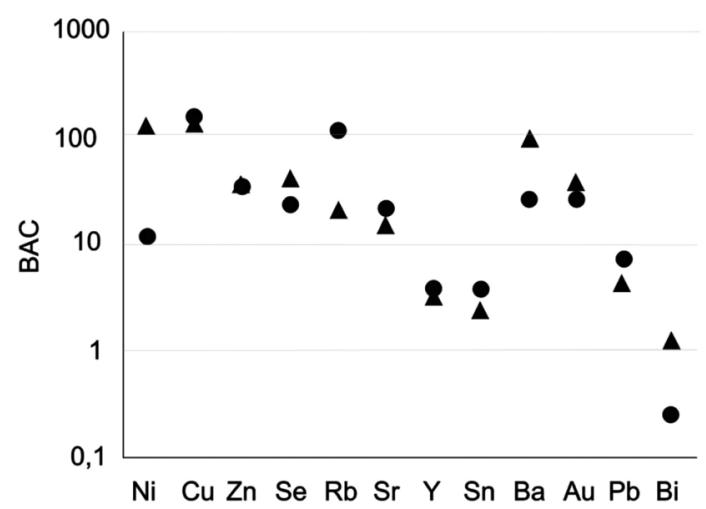

FIGURE 2 - Biologic Absorption Coefficient (BAC > 1 and $>10$ ) for plants in the volcanic terrains of the Pitinga Mine ( $\boldsymbol{\Delta}$ - maidenhair fern; $\bullet$ - saracura-mirá).

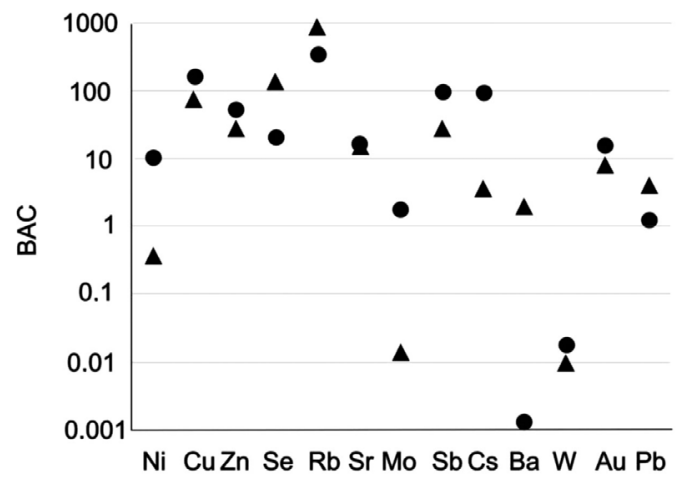

FIGURE 3 - Biologic Absorption Coefficient (BAC $>1$ and $>10)$ for plants in the granite terrains of the Pitinga Mine ( $\boldsymbol{\Delta}$ - maidenhair fern; • - saracura-mirá). 


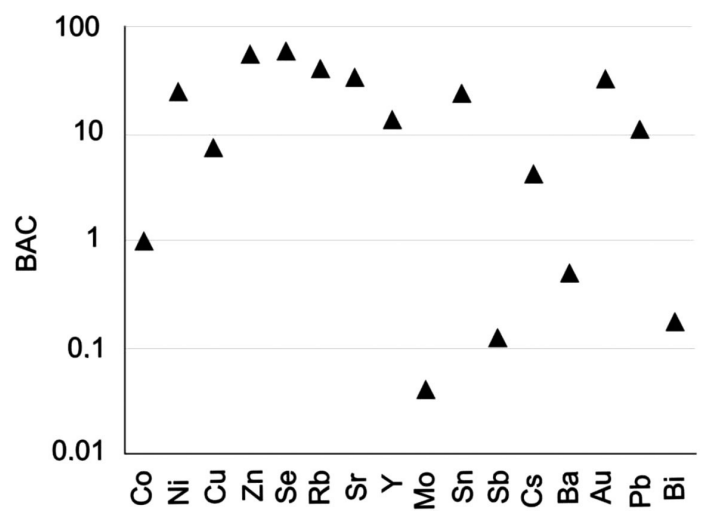

FIGURE 4 - Biological absorption coefficient (BAC) for maidenhair fern from the albite-granite-facies terrain of the Pitinga Mine.

According to KOVALEVSKY (1979), BAC greater than 10 is indicative of the mineral phase in which the element is predominantly contained. For example, in the case of $\mathrm{Zn}$, a BAC over 10 indicates the presence of sphalerite. According to that author, a BAC for Au greater than 10 indicates the occurrence of $\mathrm{Au}$ as grains scattered in clays, sulfides or iron oxides, and the high $\mathrm{BAC}$ for $\mathrm{Pb}$ indicates its presence as cerussite or anglesite, lead carbonates and sulfates.

Out of the main ore-forming elements in the Pitinga Mine ( $\mathrm{Sn}, \mathrm{Nb}, \mathrm{Ta}, \mathrm{Zr}, \mathrm{Y}$ and $\mathrm{Rb}$ ), only $\mathrm{Sn}$ and $Y$ show high values of BAC, particularly for the maidenhair fern, which can indicate the presence of mineralization. The reason for this is that the BAC behavior depends on the toxicity of the elements to the plants, and on the availability of the element in the soil. Additionally, soil samples are usually representative of a relatively small volume of material; on the other hand, the plant, through its root system, covers several cubic meters of all soil horizons, sometimes reaching up to the underlying rock. In this sense, from an exploration point of view, high concentrations of $\mathrm{Y}, \mathrm{Zr}, \mathrm{Nb}, \mathrm{Pb}, \mathrm{Sn}$ and Th in the maidenhair fern (Table 2) collected in the area of the pegmatoid cryolite deposits, are quite significant.

The comparison between the BAC of the elements in fern and saracura-mirá in both types of terrains (granitic and volcanic) shows that the fern has the highest $\mathrm{BAC}$ in the volcanic terrain, which is usually around ten times the BAC in the granitic terrain. The comparison is the opposite for $\mathrm{Rb}, \mathrm{Se}$, $\mathrm{Sb}$ and $\mathrm{Cs}$, which show higher $\mathrm{BAC}$ in the granitic areas. For the saracura-mirá, the BAC values are similar in both terrains, except for $\mathrm{Sb}$ and $\mathrm{Cs}$, which show higher BAC in the granitic terrains, and for $\mathrm{Ba}, \mathrm{Sn}$ and $\mathrm{Y}$, which show higher $\mathrm{BAC}$ in the volcanic terrains. Therefore, the absorption capacity of most of the studied elements is greater in the fern samples of the volcanic soils. The variation of the $\mathrm{BAC}$ in the same species of plant, from one terrain to the other, is probably caused by the variation in abundance of the elements in soils and rocks, as well as by the way the elements are accumulated in soils and fixed in host rocks, either granites or volcanic rocks.

$\mathrm{Ni}, \mathrm{Cu}, \mathrm{Zn}, \mathrm{Se}, \mathrm{Rb}, \mathrm{Sr}, \mathrm{Pb}$, and $\mathrm{Au}$ show high BAC in most situations, i.e., in both terrains and for both plant species. A second group, formed by $\mathrm{Ga}, \mathrm{Zr}, \mathrm{As}, \mathrm{Nb}, \mathrm{Ta}, \mathrm{Mo}, \mathrm{W}, \mathrm{Bi}$, Th, and $\mathrm{U}$, has, in general, BAC lower than 1, whereas some elements have a variable behavior. $\mathrm{Y}$ and $\mathrm{Sn}$ show BAC $>10$ for plants collected in the terrain covering the mineralization of the Pitinga Mine, which is enriched in these two elements, as well as in $\mathrm{Zr}, \mathrm{Nb}$, and Ta. In the granitic terrain, the saracura-mirá is extremely enriched in $\mathrm{Cs}$, whereas the $\mathrm{BAC}$ for $\mathrm{Ba}$ increases in the volcanic terrain. This increase is probably explained by the high concentrations of this element in the volcanic rocks of the Pitinga Mine area (PIEROSAN et al. 2011).

\section{CONCLUSIONS}

The Biological Absorption Coefficient (BAC) can be indicative of the presence of mineralization when the elements involved have moderate to high mobility; whereas the BAC for elements with low mobility, such as $\mathrm{Zr}$, $\mathrm{Nb}$, Ta, does not show a consistent variation. Particularly for the maidenhair fern samples from granitic and volcanic terrains, the high $\mathrm{BAC}$ for $\mathrm{Au}$, ranging from 8 to 40 , reinforces the possibility of using this element as an indicator of its deposits in biogeochemical exploration. Regarding sulfide mineralization, the same conclusion can be applied to $\mathrm{Cu}, \mathrm{Zn}$, and $\mathrm{Pb}$. BAC for $\mathrm{Y}$ and $\mathrm{Sn}$ increased significantly in tin mineralized areas and therefore it was proposed that this parameter could be used as an additional tool in mineral exploration.

Moreover, the results of this work suggest that $A$. amazonicus (saracura-mirá) is useful as an indicator in mineral exploration programs in the Amazonian region, as previously suggested by other authors (LIMA e CUNHA et al. 2008). Therefore, despite the difficulties faced in the Amazonian environment, such as the selection of the most representative plants, the precise 
identification of the B horizon, which is usually covered by thick layers of humus and lateritic crust, and the lack of exposed soils, the results obtained in this study support the use of biogeochemistry as a valuable tool in mineral exploration.

\section{ACKNOWLEDGEMENTS}

This work was supported by the project CTMineral/MCT/CNPq n ${ }^{\circ}$ 027/2004.

\section{REFERENCES}

ALLOWAY, B.J.; THORNTON, I.; SMART, G.A.; SHERLOCK, J.C.; QUINN, M.J. 1988. Metal availability. The Science of the Total Environment, 75: 41-69

BABULA, B.; ADAM, A.; OPATRILOVA, R.; ZEHNALEK, J.; HAVEL, L.; KIZEK, R. 2008. Uncommon heavy metals, metalloids and their plant toxicity: a review. Environmental Chemistry Letter, 6: 189-213.

BAKER, A.J.M. 1981. Accumulators and excluders-strategies in the response of plants to heavy metals. Journal of Plant Nutrition, 3(1-4): 643-654.

BASTOS NETO, A.C.; PEREIRA, V.P.; LIMA, E.F.; FERRON, J.M.T.M.; MINUZZI, O.R.R.; PRADO, M.; RONCHI, L.H.; FRANTZ, J.C.; BOTELHO, N.F.; ROLIM, S.B.; ROCHA, F.; ULMANN, L. 2005. A jazida de criolita da mina Pitinga (Amazonas). In: O.J. Marini, E.T. Queiroz, B.W. Ramos (ed.) Caracterização de depósitos minerais em distritos mineiros da Amazônia. Brasília, DNPM/CT-MINERAL/ADIMB, p. 477-552.

BASTOS NETO, A.C.; PEREIRA, V.; RONCHI, L.H.; LIMA, E.F.; FRANTZ, J.C. 2010. The Sn, Nb, Ta, F (Y, REE, Li) world class deposit and the massive cryolite deposit associated with the albite-enriched facies of the Madeira A-type granite, Pitinga mining district, Amazonas State, Brazil. Canadian Mineralogist, 47: 1328-1358.

BASTOS NETO, A.C.; PEREIRA, V.; PIRES, A.C.; BARBANSON, L.; CHAUVET, A. 2012. F-rich xenotime from the $\mathrm{Nb}-\mathrm{Ta}-\mathrm{Sn}$ Madeira world-class deposit associated with the albiteenriched granite at Pitinga (Amazonian, Brazil). Canadian Mineralogist, 50: 1453-1466.
BORGES, R.M.K.; DALL'AGNOL, R.; COSTI, H.T. 2003. Geologia, Petrografia e Química Mineral das Micas dos Greisens Estaníferos Associados ao Pluton Agua Boa, Pitinga (AM). Revista Brasileira de Geociências, 33(1): 51-62

BROOKS, R.R. 1983. Biological methods of prospecting for minerals. Wiley, New York, $322 \mathrm{p}$.

COSTA, M.L. 1991. Aspectos Geológicos dos Lateritos da Amazônia. Revista Brasileira de Geociências, 21(2): 146-160.

COSTI, H.T. 2000. Petrologia de Granitos Alcalinos com Alto Flúor Mineralizados em Metais Raros: o Exemplo do Albita Granito da Mina Pitinga, Amazonas, Brasil. Centro de Geociências, Universidade Federal do Pará, Belém, Tese de Doutorado, 345 p.

DAOUD, W.K. 1988. Granitos estaníferos de Pitinga, Amazonas: contexto geológico e depósitos minerais associados. Instituto de Geociências, Universidade de Brasília, Brasília, Dissertação de Mestrado, 194 p.

DUNN, C.E. 1995. Mineral Exploration Beneath Temperate Forests: The Information Supplied by Trees. Exploration Mining Geology, 4(3): 197-204.

DUNN, C.E. 2007. Biogeochemistry in Mineral Exploration. Handbook of Exploration and Environmental Geochemistry, v.9, Elsevier, $462 \mathrm{p}$.

DUNN, C.E.; ANGÉLICA, R.S. 2000. Evaluation of biogeochemistry as a tool in mineral exploration and in monitoring environmental Mercury dispersion in the Tapajós Gold District, Amazonia, Brazil. Geological Survey of Canada, Open File 3838.

EBONG, G.A.; ETUK, H.S.; JOHNSON, A.S. 2007. Heavy Metals Accumulation by Talinum triangulare grown on Waste Dumpsites in Uyo Metropolis, Akwa Ibom State, Nigeria. Journal of Applied Sciences, 7(10): 1404-1409.

FERRON, J.M.T.M.; BASTOS NETO, A.C.; LIMA, E.F.; NARDI, L.V.S.; COSTI, H.T.; PIEROSAN, R.; PRADO, M. 2010. Petrology, Geochemistry and Geochronology of 
Paleoproterozoic Volcanic and Granitic Rocks (1.89 to $1.88 \mathrm{Ga}$ ) of the Pitinga Province, Amazonian Craton, Brazil. Journal of South America Earth Science, 53(8): 946-979.

GREGER, M. 2004. Metal availability, uptake, transport and accumulation in plants. In: M.N.V. Prasad (ed.) Heavy metal stress in plants: From biomolecules to ecosystems. $2^{\text {nd }}$ ed., Berlin, Springer, p. 1-27.

HORBE, A.M.C.; COSTA, M.L. 1999. Geochemical evolution of a lateritic $\mathrm{Sn}-\mathrm{Zr}$ Th-Nb-Y-REE bearing ore body derived from apogranite: the case of Pitinga, Amazonas Brazil. Journal of Geochemical Exploration, 66: 339-351.

HORBE, A.M.C; PEIXOTO S.F. 2006. Geochemistry of Pitinga Bauxite Deposit - Amazonian Region - Brazil. In: R.W. Fitzpatrick \& P. Shand (ed.) Regolith Consolidation and Dispersion of Ideas. The CRC Leme Regolith Symposium, Hahndorf Resort, Proceedings, p. 144-146.

HORBE, M.A.; HORBE, A.C.; COSTI, H.T.; TEIXEIRA, J.T. 1991. Geochemical characteristics of cryolite - tin-bearing granites from the Pitinga Mine, Northwestern Brazil - a review. Journal of Geochemical Exploration, 40: 227-249.

KABATA-PENDIAS, A.; PENDIAS H. 1984. Trace elements in soils and plants. CRC, Boca Raton, 315 p.

KOVALEVSKY, L.A. 1979. Biogeochemical Exploration for Mineral Deposits. Oxonian Press PVT, Nova Delhi, 136 p.

LENHARO, S.L.R. 1998. Evolução magmática e modelo metalogenético dos granitos mineralizados da região de Pitinga, Amazonas, Brasil. Departamento de Engenharia de Minas, Escola Politécnica, Universidade de São Paulo, São Paulo, Tese de Doutorado, 290 p.

LENHARO S.L.R.; POLLARD, P.J.; BORN, H. 2000. Matrix rock texture in the Pitinga Topaz Granite, Amazonas, Brazil. Revista Brasileira de Geociências, 30(2): 238-241.

LIMA E CUNHA, M.C.; MARIATH, J.E.A.; MENEGOTTO, E.; FORMOSO, M.L.L.
2004. Diagnose de Microbiólitos Metálicos em Espécies Vegetais Endêmicas em Solos de Rochas Ultramáficas por Microscopia Eletrônica de Varredura. Pesquisas em Geociências, 31(1): 17-28.

LIMA E CUNHA, M.C.; PEREIRA, V.P.; MENEGOTTO, E.; BASTOS NETO, A.C.; OLIVEIRA, E.L.O.; FORMOSO, M.L.L. 2008. Biogeochemical behavior of Ampelozizyphus amazonicus Ducke in the Pitinga mining district, Amazon, Brazil. Environmental Geology, 55: 1355-1362.

LIMA E CUNHA, M.C.; PEREIRA, V.P.; NARDI, L.V.S.; BASTOS NETO, A.C.; VEDANA, L.A.; FORMOSO, M.L.L. 2012. REE Distribution Pattern in Plants and Soils from Pitinga Mine -Amazon, Brazil. Open Journal of Geology, 2: 253-259.

MIAO, L.; MA, Y.; XU, R.; YAN, W. 2011. Environmental biogeochemical characteristics of rare earth elements in soil and soil-grown plants of the Hetai goldfield, Guangdong Province, China. Environmental Earth Science, 63: 501-511.

MINUZZI, O.R.R.; BASTOS NETO, A.C.; FORMOSO, M.L.L.; ANDRADE, S.; JANASI V.A.; FLORES, J.A.A. 2008. Rare earth element and yttrium geochemistry applied to the genetic study of cryolite ore at the Pitinga mine (Amazon, Brazil). Anais da Academia Brasileira de Ciências, 80: 719-733.

NARDI, L.V.S.; FORMOSO, M.L.L.; JARVIS, K.; OLIVEIRA, L.; BASTOS NETO, A.C.; FONTANA, E. 2012. REE, Y, Nb, U, and Th contents and tetrad effect in zircon from a magmatic-hydrothermal F-rich system of Snrare metal-cryolite mineralized granites from the Pitinga Mine, Amazonia, Brazil. Journal of South American Earth Sciences, 33(1): 34-42.

PIEROSAN, R.; LIMA, E.F.; NARDI, L.V.S.; CAMPOS, C.P.; BASTOS NETO, A.C.; JARVIS, K.; FERRON, J.M.; PRADO, M., 2011. Geochemistry of Palaeoproterozoic volcanic rocks of the Iricoumé Group, Pitinga Mining District, Amazonian craton, Brazil. International Geology Review, 53(8): 946-979. 
PIRES, A.C.; BASTOS NETO, A.C.; PEREIRA, V.P.; BOTELHO, N.F. 2006. A gagarinita(Y) do granito Madeira (Pitinga, Amazonas): exsolução de ETRL a partir de fluoreto metaestável e formação de um possível novo mineral semelhante à fluocerita. Revista Brasileira de Geociências, 36 (1): 155-164.

SCHEIB, A.J.; FLIGHT, D.M.A.; BIRKE, M.; TARVAINEN, T.; LOCUTURA, J.; GEMAS Project Team. 2012. The geochemistry of niobium and its distribution and relative mobility in agricultural soils of Europe.
Geochemistry: Exploration, Environment, Analysis, 12: 293-302.

WELCH, G.R. 1984. Biochemical dynamics in organized states: A holistic approach. In: J. Ricard \& A. Cornish-Bowen (ed.). Dynamics of Biochemical Systems. New York, Plenum Press, p. 85-101.

WHITE, P.J.; BROADLEY, M.R. 2000. Mechanisms of caesium uptake by plants. New Phytology, 147: 241-256 (Tansley Review $\mathrm{N}^{\mathrm{o}} 113$ ).

\section{Endereço dos autores:}

Maria do Carmo Lima e Cunha, Lauro Valentim Stoll Nardi, Vitor Paulo Pereira e Artur Cezar Bastos Neto - Centro de Estudos em Geoquímica e Petrologia, Instituto de Geociências, Universidade Federal do Rio Grande do Sul, Caixa Postal 15001, Porto Alegre, RS, Brasil.E-mails: maria.cunha@ufrgs.br; lauro. nardi@ufrgs.br; vitor.pereira@ufrgs.br; artur.bastos@ufrgs.br

Luiz Alberto Vedana - Curso de Pós Graduação em Geociências, Instituto de Geociências, Universidade Federal do Rio Grande do Sul, Caixa Postal 15001, Porto Alegre, RS, Brasil.E-mail: luizvedana@gmail.com

Artigo submetido em 21 de maio de 2014, aceito em 12 de agosto de 2014. 


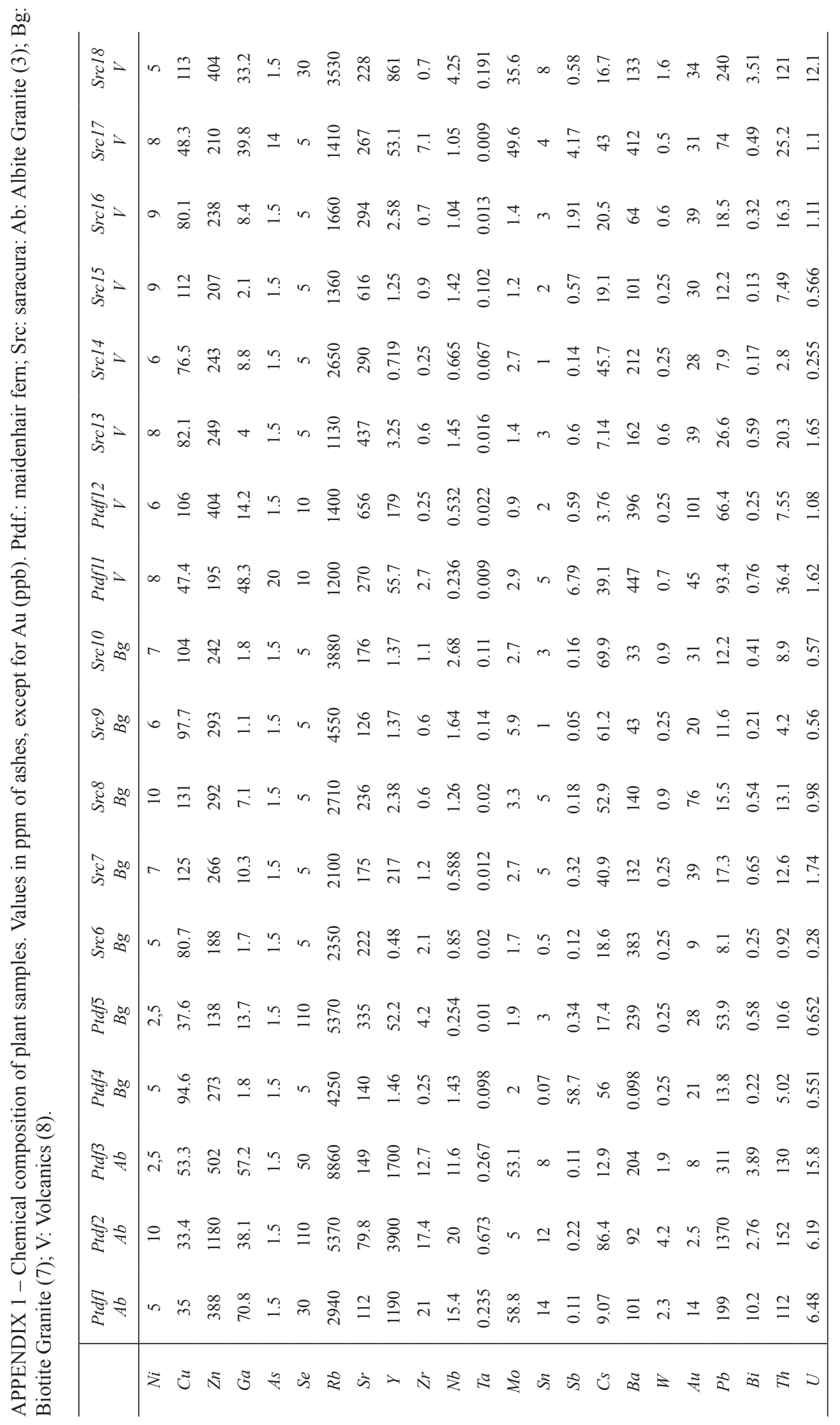




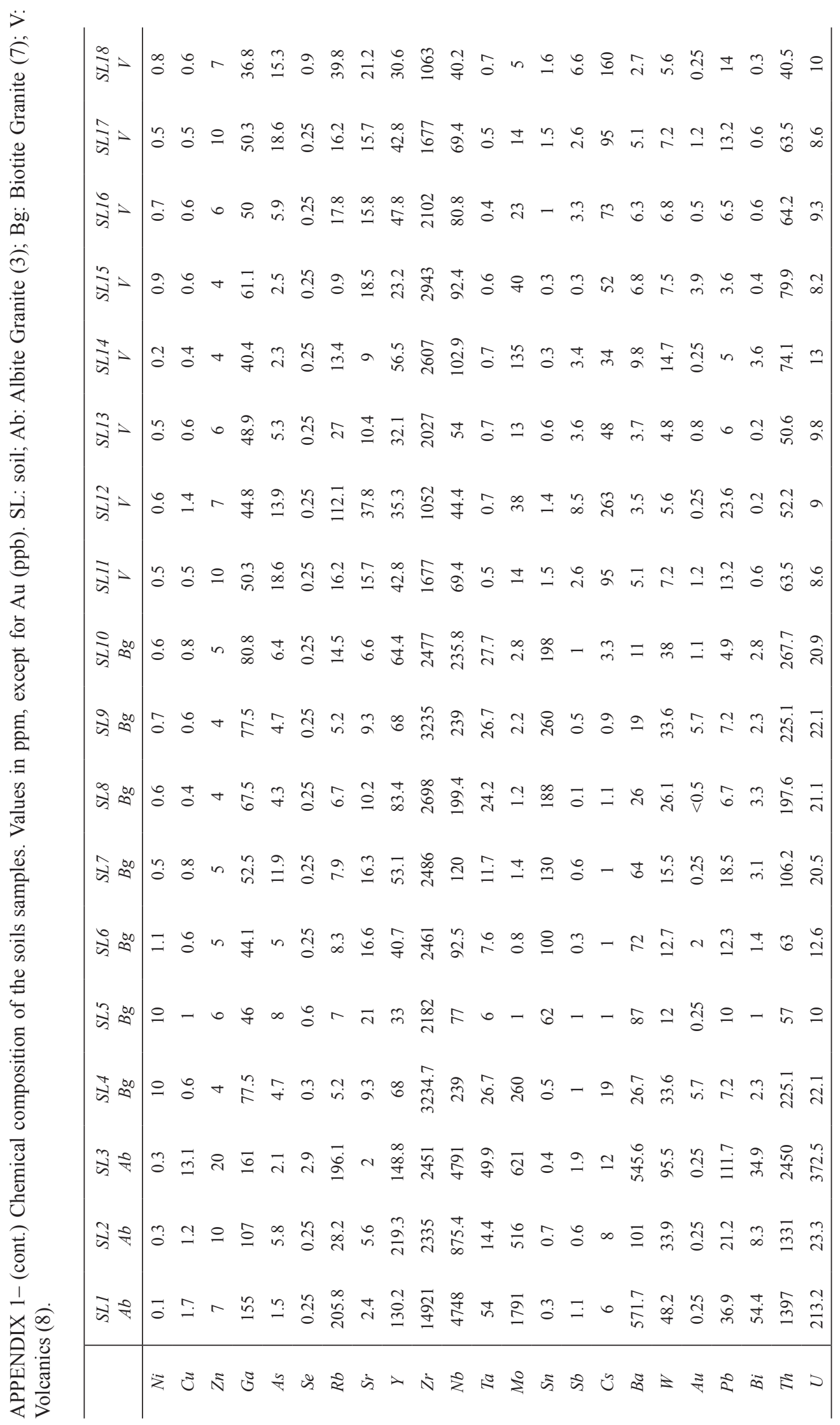

